\title{
Temporal polyethism, life expectancy, and entropy of workers of the ant Ectatomma vizottoi Almeida, 1987 (Formicidae: Ectatomminae)
}

\author{
Alexsandro Santana Vieira • \\ Wedson Desidério Fernandes • \\ William Fernando Antonialli-Junior
}

Received: 25 June 2009 /Revised: 4 February 2010 /Accepted: 12 April 2010 /Published online: 4 May 2010

(C) The Author(s) 2010. This article is published with open access at Springerlink.com

\begin{abstract}
We investigated the changes in the behavioral repertoire over the course of life and determined the life expectancy and entropy of workers of the ant Ectatomma vizottoi. Newly emerged ants were individually marked with model airplane paint for observation of behaviors and determination of the age and life expectancy. Ants were divided into two groups: young and old workers. The 36 behaviors observed were divided into eight categories. Workers exhibit a clear division of tasks throughout their lives, with young workers performing more tasks inside the colony and old workers, outside, unlike species that have small colonies. This species also exhibits an intermediate life expectancy compared to workers of other species that are also intermediary in size. This supports the hypothesis of a relationship between size and maximum life expectancy, but it also suggests that other factors may also be acting in concert. Entropy value shows a high mortality rate during the first life intervals.
\end{abstract}

Keywords Division of labor · Entropy · Life expectancy

A. Santana Vieira $(\bowtie) \cdot$ W. Desidério Fernandes •

W. Fernando Antonialli-Junior

Programa de Pós-graduação em Entomologia e Conservação da

Biodiversidade, Universidade Federal da Grande Dourados,

Faculdade de Ciências Biológicas e Ambientais, 241,

79804-970 Dourados, Mato Grosso do Sul, Brazil

e-mail: alexbcm@rc.unesp.br

W. Fernando Antonialli-Junior

Laboratório de Ecologia, Centro Integrado de Análise

e Monitoramento Ambiental,

Universidade Estadual de Mato Grosso do Sul. 351,

79804-907 Dourados, Mato Grosso do Sul, Brazil

\section{Introduction}

The reproductive success of social insects is largely attributed to the division of labor between reproductive and sterile individuals (Gronenberg 1996). This has been an important subject to understand the evolution of social behavior (Oster and Wilson 1978; Bourke and Franks 1995). Division of labor may or may not be associated with morphology and consequently to worker size, known as caste polyethism, in which larger workers forage while smaller workers perform within-nest tasks (Oster and Wilson 1978). When this is not the case, division of labor may be associated with a temporary caste, where groups of individuals are specialized in particular tasks based on age for a given period of time, termed age polyethism (Wilson 1971; Fresneau et al. 1982; Fresneau 1984; Oster and Wilson 1978).

Age polyethism is currently referred to, more neutrally, temporal polyethism, which describes the process of task allocation over time (Bourke and Franks 1995). This change of emphasis occurred because most of the existing data on age polyethism only show a correlation between age and task (e.g., Calabi and Rosengaus 1988, Corbara et al. 1989, Dejean and Lachaud 1991. Temporal polyethism is very common among social insects, particularly among ants (Wilson 1971; Calabi 1989), with younger workers performing within-nest tasks and older workers foraging for the colony (Caetano et al. 2002). According to MacDonald and Topoff (1988), temporal polyethism is usually associated with physiological changes, when the period of developing ovaries corresponds with the age when workers care for the brood and queen. Reabsorption of ovaries occurs in the next stage, and the development of the poison gland corresponds with a period when workers perform activities associated with defense and foraging. 
The level of temporal polyethism varies widely among social insects and appears to be correlated with colony size (Wilson 1971; Jeanne 1999; Thomas and Elgar 2003). Inter-specific comparative studies suggest that task specialization and polyethism are influenced by colony size (Bourke 1999, Anderson and McShea 2001). Species with larger colonies typically have greater spatial organization of work, caste polymorphism, and shorter queuing delays in task partitioning (Wilson 1971). In colonies of ants, bees, wasps, and termites composed of thousands to millions of workers, tasks in the colony are divided among highly specialized workers (Möglich and Hölldobler 1974; Hölldobler and Wilson 1990; Crosland et al. 1997). In contrast, in small colonies with less than one hundred workers, individuals tend to be more generalists and perform multiple types of daily tasks, such as in Bombus bees studied by Cameron and Robinson (1990), Polistes wasps by Post et al. (1988), and small ant colonies of Rhytidoponera metallica by Thomas and Elgar (2003). Thus, variations in temporal polyethism may reflect different levels of social organization of insects based on their phylogenetic profile, with highly eusocial species tending to be ergonomically more specialized compared to primitive species. (Hölldobler and Wilson 1990; Jaisson et al. 1992).

Poneromorph ants (Bolton 2003) are suitable for comparative studies of social organization as they are primitive evolutionarily, behaviorally, as well as morphologically (Wheeler 1910; Wilson 1971; Hölldobler and Wilson 1990). In poneromorph subfamilies, temporal polyethism has been observed in Pachycondyla villosa (PérezBautista et al. 1985), Pachycondyla (Neoponera) apicalis (Fresneau and Dupuy 1988), Platythyrea lamellosa (Villet 1990), Odontomachus troglodytes (Dejean and Lachaud 1991), Amblyopone silvestrii (Masuko 1996); in the genus Ectatomma, in Ectatomma tuberculatum (Champalbert and Lachaud 1990; Fénéron and Jaisson 1994), Ectatomma brunneum (quadridens) (Overal 1986), Ectatomma planidens (Antonialli-Junior and Giannotti 2003), and Ectatomma opaciventre (Pie 2002; Miguel and Del-Claro 2005). On the other hand, temporal polyethism was not observed in Pachycondyla caffraria (Agbogba 1994) and Amblyopone pallipes (Traniello 1978).

Division of labor may influence the life expectancy of workers of social insects. Antonialli-Junior et al. (2007) reported that the life expectancy of $E$. planidens workers gradually decreases after the onset of foraging. However, few studies have examined the life expectancy of workers. In ants, little information is available on queens (Hölldobler and Wilson 1990). Studies on younger workers that perform intranidal tasks and older workers that perform extranidal activities have investigated the relationship between age and behavior: Cammaerts-Tricot and Verhaeghe (1974) correlate age and the distance ants follow a of poison gland extract;
Cammaerts-Tricot (1975) describes the effect of age on the response to an ant of another species; Higashi (1974) describes mandibular wear in intranidal vs. extranidal nest construction; Rosengren (1977) compares behavior of younger and older foragers; Weir (1958a) compares nest construction activities in older and younger workers. Gordon (1984), Wilson and Brown (1984) and Miguel and Del-Claro (2005) examined whether younger ants perform intranidal tasks while older workers, outside the nest.

Given the importance of division of labor for the understanding of the level of social organization of insects, this study investigated whether temporal polyethism occurs in E. vizottoi workers, and its relationship with life expectancy and entropy under laboratory conditions.

\section{Materials and methods}

Two E. vizottoi colonies were collected at the campus of the State University of Mato Grosso do Sul/UEMS, in Dourados-MS (22 $\left.13^{\prime} 16^{\prime \prime} ; 54^{\circ} 48^{\prime} 20^{\prime \prime}\right)$. The underground nests were excavated according to Antonialli-Junior and Giannotti (2001), transferred to artificial nests (AntonialliJunior and Giannotti 2002; 2003), and maintained at a constant temperature of $26^{\circ} \mathrm{C}$ and natural light cycle.

\section{Temporal polyethism}

Wilson (1971) and Miguel and Del-Claro (2005) observed that newly emerged workers can be identified by their pale coloration compared to older workers. Thus, each newly emerged ant was individually marked on the thorax with model airplane paint (Nakata 1996), using five different colors in paired combinations, objective of which is to monitor the age of the ant. This procedure allowed the observation of behaviors ants before and after foraging during their life, resulting into two age groups: young workers, defined as those that do not forage, and old workers, which perform this task (Hölldobler and Wilson 1990).

Thirty-five workers were used in the study. To establish the behavioral repertoire of the two classes of workers $93 \mathrm{~h}$ of observation were conducted following the scanning method described by Altmann (1974), totaling 10,131 records. The behavioral repertoire of these two groups was analyzed with Cluster grouping by Morisita-Horn tests (multivariate analysis), proper to show percentage data (Wolda 1981).

Determination of life expectancy and entropy

The relative frequency that each one of the two groups (young and old workers) performed each behavior of the 
eight categories was calculated by the expression: $F_{\mathrm{r}}=F_{\mathrm{i}} / n$, where $F_{\mathrm{i}}=$ absolute frequency of each behavior and, $n=$ total number of observations of all behaviors.

A classic method of life table to calculate the life expectancy of insects has been developed by Krebs (1994) and Silveira Neto et al. (1976). However, some authors including Fernandes et al. (2003), Tofolo and Giannotti (2005), Krüger and Erthal (2006) and Antonialli-Junior et al. (2007) used an equivalent method developed by Carey (1993).

For the construction of the life table, 102 individually marked workers as previously described were used, and the parameter described by Carey (1993) was estimated by:

$T_{x}=\sum_{x=0}^{w} L_{x}$

where $T_{x}=$ total number of days at age $x$ of survivors until the last possible day of life; $x=$ age interval of 1 day; $w=$ maximum age in days reached by the last surviving individual; $L_{x}=$ average of probability of survivors between successive ages, calculated as $L_{x}=1_{x}-\left(d_{x}\right) / 2 ; 1_{x}=$ proportion of survivors among newly emerged workers in relation to age interval; $d_{x}=$ proportion of individuals that died between age $x$ and $x+1$, calculated as $\mathrm{d}_{\mathrm{x}}=1_{\mathrm{x}}-1_{\mathrm{x}+1}$; The remaining life expectancy $\left(e_{x}\right)$ of individuals at the beginning of each age interval was calculated as $e_{x}=T_{x} / 1_{x}$. The entropy $(\mathrm{H})$, a measurement of the heterogeneity in the survival pattern defined as the ratio between the number of days lost by the population due to deaths and the number of days that workers lived was calculated by the equation:

$H=\sum_{x=0}^{w} e_{x} d_{x} / e_{0}$

where $e_{x}=$ life expectancy at age $x ; d_{x}=$ proportion of individuals that died between the ages $x$ and $x+1 ; e_{0}=$ life expectancy at the initial age, and $w=$ maximum age reached by the last surviving individual.

\section{Results}

Temporal polyethism

The average age of the onset of activities outside the nest by workers was $95.774 \pm 35.674$ days. Thirty-five behaviors were performed by young workers and 32 , by old workers. The method of Cluster grouping pointed differences between the repertoires of the two groups: old and young workers (Fig. 1).

Over the course of their lives, workers performed activities inside and outside the nest that were grouped into eight behavioral categories: body grooming, brood care,

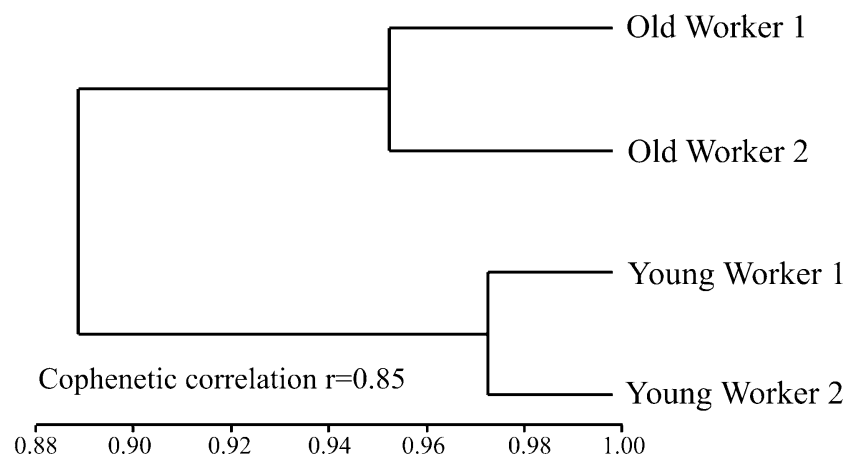

Fig. 1 Dendrogram similarity (Morisita-Horn) among the two workers groups of Ectatomma vizottoi. Young workers 1 young workers colony 1 , Young workers 2 young workers colony 2, Old workers 1 old workers colony 1 , Old workers 2 old workers colony 2

feeding, nest defense, colony maintenance, communication, immobility, and other behaviors (Fig. 2 and Table 1). Young workers spent more time tending the brood, followed by body grooming and feeding. Old workers spent more time in activities related to colony maintenance and defense, and immobility (Fig. 2 and Table 1): young workers spent $26 \%$ of the time immobile, while old workers $40 \%$.

\section{Life expectancy}

The average life expectancy of workers was $212.00 \pm$ 122.253 days, and the maximum life expectancy was 423 days. The life expectancy in the first life interval was $\mathrm{e}_{\mathrm{x}}=138.89$, reaching 244.12 at the 31 st day of life, followed by relative stabilization until the 53rd day and then a gradual decrease (Fig. 3). A high mortality rate (46.6\%) occurred during the first 53 days of life, and only $36.3 \%$ of the individuals survived after reaching the average life expectancy.

\section{Entropy}

The entropy found for E. vizottoi workers was $H=0.920$ (Fig. 4), indicating a high mortality rate during the first life intervals. The survival curve remained between 0.5 and 1.0 until the last life interval (Fig. 4). Because of the high number of deaths during the first 53 days of life, the survival curve for this species has a convex aspect, stabilizing between 54 and 151 days of life, without deaths. After this age, there is a gradual increase in deaths (Fig. 4).

\section{Discussion}

The average age when workers begin to perform activities outside the nest was similar to that observed in $E$. edentatum workers (Antonialli-Junior and Giannotti 
2003), which start foraging with an average age of 97 days. In contrast, E. tuberculatum workers (Champalbert and Lachaud 1990) begin performing activities outside the nest with less than 45 days of age. Similarly, the ponerine Ponera pennsylvannica begins to perform these activities between one and five days of age, although older workers are more frequently observed (Pratt et al. 1994). In $P$. caffraria colonies, 6 days after emergence, some newly emerged workers perform within-nest tasks, while others forage outside (Agbogba 1994). However, this is probably influenced by colony size, since in small colonies, younger workers tend to forage at an earlier age (Hölldobler and Wilson 1990).

Young E. vizottoi workers perform more activities associated with brood care and other within-nest activities. Old workers perform activities involving colony maintenance, especially foraging. Similarly, other species of the genus, such as E. tuberculatum (Fénéron et al. 1996), E. planidens (Antonialli-Junior and Giannotti 2003) and E. opaciventre (Miguel and Del-Claro 2005), as well as other poneromorph ants, such as Gnamptogenys horni (Hölldobler and Wilson 1990, Pratt 1994), P. pennsylvannica (Pratt et al. 1994), Pachycondyla sublaevis (Ito and Higashi 1991), P. (Neoponera) apicalis (Fresneau and Dupuy 1988), O. troglodytes (Dejean and Lachaud 1991), and A. silvestrii (Masuko, 1996) also exhibit a clear division of tasks between young and old ants. In contrast, workers of P. caffraria (Agbogba 1994) and A. pallipes (Traniello 1978) do not exhibit this pattern.

According to Gordon et al. (2005), the transition from inside to outside work is extremely variable and it seems to be typical of ants that exhibit temporal polyethism. Hölldobler and Wilson (1990) reviewed studies on temporal castes and only 16 species exhibited "typical age polyethism," characterized by younger workers tending the brood and queen, and older workers transitioning to nest work, followed by foraging (Hölldobler and Wilson 1990). Other studies reported that younger ants perform tasks inside and older ones work outside the nest (McDonald and Topoff 1985; Wilson and Hölldobler 1986). Gordon et al. (2005), studying the red harvester ant Pogonomyrmex barbatus (Myrmicinae), reported the sequence of tasks performed by marked individuals in three laboratory colonies and observed that ants often move from inside to outside tasks. However, there was a wide variation in this sequence.

The social organization of highly eusocial species of bees and wasps share several convergent characteristics, including prominent temporal polyethism, and division and specialization of tasks (O'Donnell and Jeanne, 1993). Workers of Polybia occidentalis, a species considered highly eusocial among Vespidae, perform more specialized tasks than workers of "primitively eusocial wasps" (Jeanne 1991).

In addition, age-correlated division of labor may be influenced by the number of individuals in the colony. In large colonies, age-correlated division of labor may be more specialized, whereas in smaller colonies, the behavioral repertoire of individuals appears to be more flexible, such as in the ant $R$. metallica (Thomas and Elgar 2003).

In fact, Thomas and Elgar (2003) found differences in task specialization between large colonies ( $>450$ workers), and small colonies ( $<80$ workers). These authors also observed temporal polyethism in large but not small colonies. In large colonies, old workers spent significantly more time foraging than young workers, while young
Fig. 2 Relative frequency of the eight categories of behaviors of Ectatomma vizottoi workers

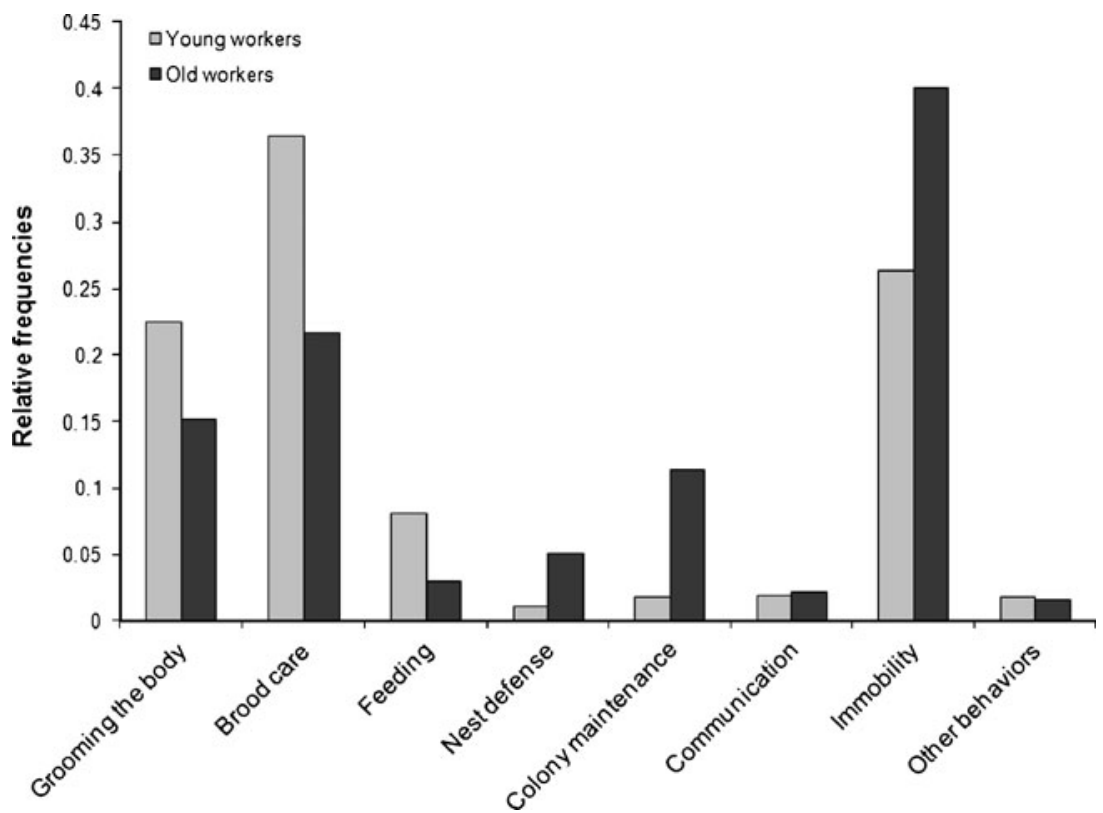


Table 1 Comparative ethogram of young and old workers into two colonies Ectatomma vizottoi Almeida 1987 under laboratory conditions
The values are given as relative frequencies

\begin{tabular}{|c|c|c|c|}
\hline \multicolumn{2}{|c|}{ Behavioral categories } & Young workers & Old workers \\
\hline \multicolumn{4}{|c|}{ Grooming of the body } \\
\hline 1 & Self-grooming/1st leg pair & 0.08495 & 0.05973 \\
\hline 2 & Self-grooming/2nd leg pair & 0.02508 & 0.00853 \\
\hline 3 & Self-grooming/3rd leg pair & 0.02493 & 0.00853 \\
\hline 4 & Self-grooming/ extremity of the gaster & 0.00600 & 0.00358 \\
\hline 5 & Self-grooming/ mandibles & 0.00015 & - \\
\hline 6 & Allogrooming in workers & 0.07572 & 0.06689 \\
\hline 7 & Allogrooming in queens & 0.00677 & 0.00440 \\
\hline 8 & Allogrooming in males & 0.00154 & - \\
\hline \multicolumn{4}{|c|}{ Brood care } \\
\hline 9 & Standing on top of or by the eggs & 0.01385 & 0.00661 \\
\hline 10 & Inspecting eggs & 0.00108 & - \\
\hline 11 & Carrying eggs & 0.00031 & 0.00028 \\
\hline 12 & Licking eggs & 0.00139 & 0.00138 \\
\hline 13 & Standing on top of or by the side of larvae & 0.12450 & 0.07817 \\
\hline 14 & Inspecting larvae & 0.03032 & 0.01266 \\
\hline 15 & Carrying larvae & 0.00169 & 0.00138 \\
\hline 16 & Licking larvae & 0.08156 & 0.03496 \\
\hline 17 & Helping larvae to pupate & 0.00508 & 0.00138 \\
\hline 18 & Standing on top of or by thepupae & 0.07156 & 0.05065 \\
\hline 19 & Inspecting pupae & 0.02585 & 0.02257 \\
\hline 20 & Carrying pupae & 0.00154 & 0.00303 \\
\hline 21 & Licking pupae & 0.00508 & 0.00330 \\
\hline \multicolumn{4}{|c|}{ Feeding } \\
\hline 22 & Feeding larvae with solid food & 0.02601 & 0.00523 \\
\hline 23 & Worker-larva food transfer & 0.00215 & 0.00083 \\
\hline 24 & Solid feeding in the nest & 0.04601 & 0.02147 \\
\hline 25 & Cannibalism of immatures & 0.00569 & 0.00193 \\
\hline 26 & Eating refuse & 0.00108 & 0.00055 \\
\hline 27 & Ovipositing trophic eggs & 0.00015 & - \\
\hline \multicolumn{4}{|c|}{ Nest defense } \\
\hline 28 & Guarding the entrance to the nest & 0.01062 & 0.05037 \\
\hline \multicolumn{4}{|c|}{ Colony maintenance } \\
\hline 29 & Foraging solid/Collecting fluid & - & 0.07900 \\
\hline 30 & Carrying material in the nest & 0.00015 & 0.00055 \\
\hline 31 & Carrying refuse & 0.00108 & 0.00165 \\
\hline 32 & Licking walls of the chamber & 0.00123 & 0.00083 \\
\hline 33 & Inspecting the nest & 0.01600 & 0.03193 \\
\hline \multicolumn{4}{|c|}{ Communication } \\
\hline 34 & Touch workers with antennae & 0.01939 & 0.02147 \\
\hline \multicolumn{4}{|c|}{ Immobility } \\
\hline 35 & Immobility & 0.26377 & 0.40077 \\
\hline \multicolumn{4}{|c|}{ Other behaviors } \\
\hline 36 & Moving inside the nest & 0.01770 & 0.01541 \\
\hline
\end{tabular}

workers spent more time caring for brood. In small colonies, young and old workers spent similar amounts of time foraging and tending the brood. In the present study, the colonies of $E$. vizotto $i$ were small with approximately
60 to 90 workers (Vieira et al. 2007). However, the tasks performed by young workers significantly differ from those performed by older workers, although with similarities between the two groups. 
Fig. 3 Life expectancy of Ectatomma vizottoi under laboratory conditions

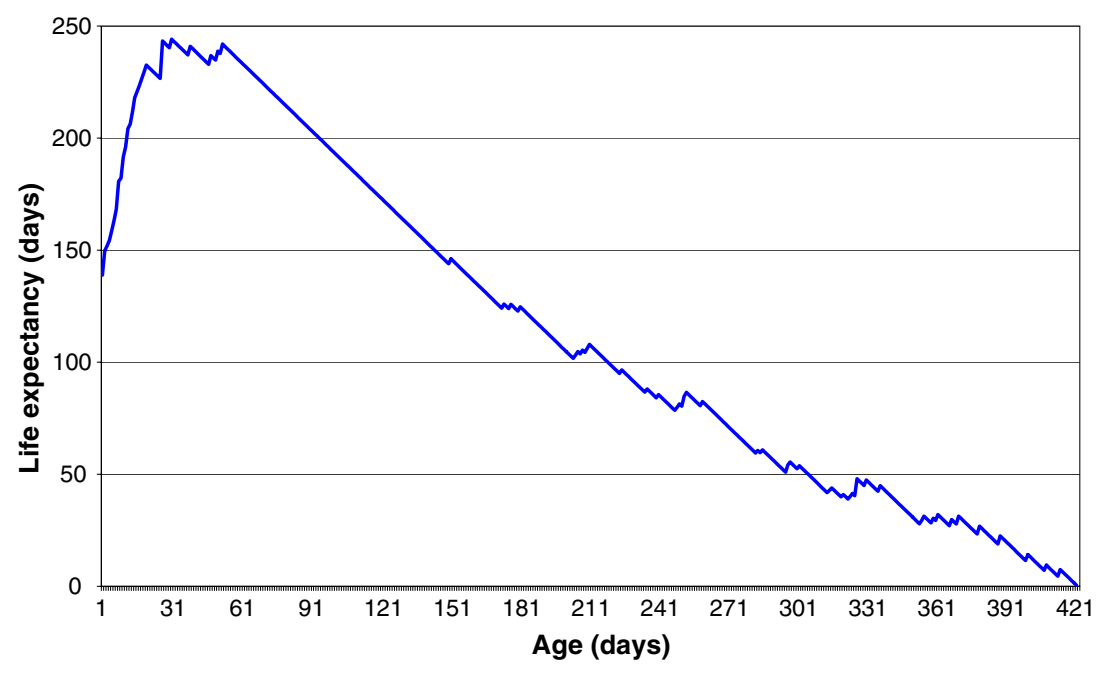

Ant colonies of primitive lineages, such as Amblyoponinae and poneromorph ants, vary in size from dozens (see $A$. pallipes Traniello 1978; Dinoponera quadriceps Dantas-deAraújo and Jaisson (1994) to hundreds of individuals (see $E$. tuberculatum Hora et al. 2005; Paraponera clavata Breed and Harrison 1988). Thus, prominent polyethism would not be expected in primitive groups, especially in smaller colonies, since workers may start foraging earlier, due to the needs of the colony.

Possible reasons for the onset of foraging might be the need of resources or simply an intrinsic characteristic of the species. This is probably influenced by colony size, since in small colonies, younger workers tend to forage at an earlier age. Old workers from large colonies of $R$. metallica spent significantly longer periods of time foraging than individuals from small colonies, who typically have shorter foraging bouts (Thomas 2002). However, larger colonies may require more food to sustain their larvae and adults (Thomas and Elgar 2003).
The activities associated with brood care are also primarily performed by young workers, as also observed in E. planidens colonies (Antonialli-Junior and Giannotti 2003). Champalbert and Lachaud (1990) studying $E$. tuberculatum, concluded that behavioral specializations progressively appear with age, and there is a sensitive period when social stimulus affects the establishment of behaviors associated with brood care. The fact that workers at this age spend more time caring for the brood explains the higher frequency of cannibalism of immature individuals, as they have more contact with eggs, larvae, and pupae and are more likely to detect any type of physical or physiological problems during these different immature stages (Wilson 1971; Antonialli-Junior and Giannotti 2003). Also, Tofolo and Giannotti (2005), studying E. brunneum, hypothesized that in the laboratory, due to space limits, workers regulate the size of the colony with cannibalism.
Fig. 4 Survirvorship curve of Ectatomma vizottoi under laboratory conditions

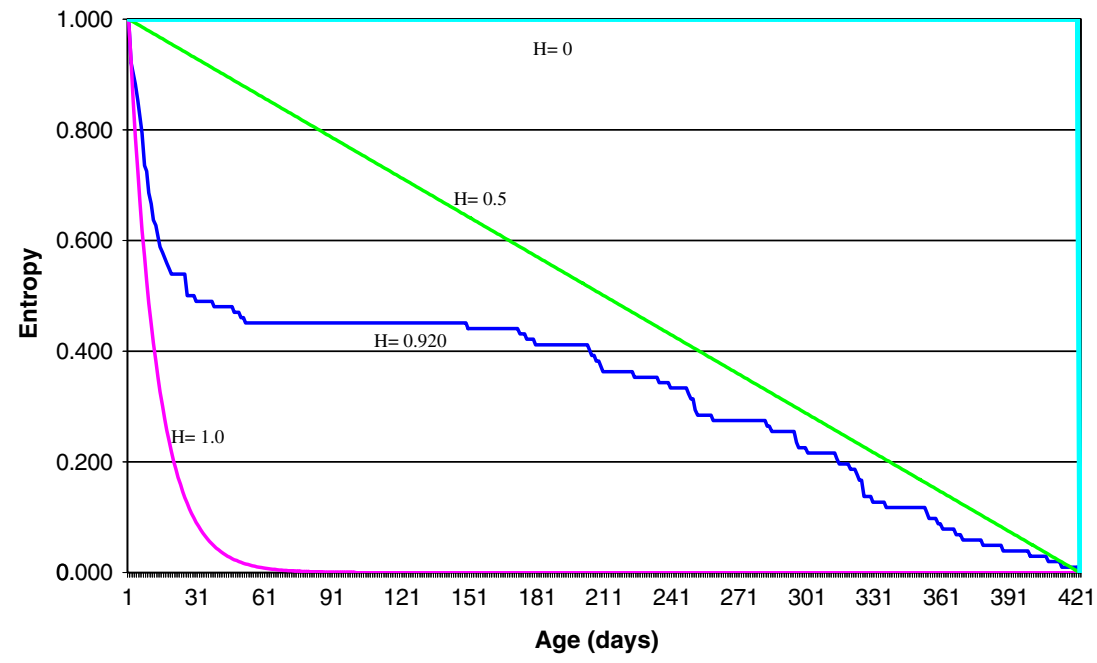


According to Gordon et al. (2005), temporal polyethism and/or the progression from one task to another is the product of interacting factors, such as spatial distribution. For other authors, this is a consequence of physiological changes that occur as individuals age (Macdonald and Topoff 1988, Billen 1982, Fénéron et al. 1996, Robinson et al. 1994). Fénéron et al. (1996) found a relationship between behavior and physiological maturation in $E$. tuberculatum workers, where the behavioral ontogeny from brood care to foraging activity appears to be closely related to glandular changes. Another factor is the current needs of the colony and the environment. When workers are removed from the colony, other workers change tasks (McDonald and Topoff 1985). Also, some individuals are consistently more active throughout their lives, than others, and these more active individuals are more likely to perform tasks outside the nest (e.g., Retana and Cerdá 1991).

The average life expectancy of E. vizottoi workers was longer than the 188.23 days reported for E. planidens workers (Antonialli-Junior et al. 2007), although E. brunneum workers (Tofolo and Giannotti 2005) have an average life expectancy of 1.6 years. According to Hölldobler and Wilson (1990), variations in life expectancy might reflect differences in body size, which would explain the differences described above, as E. planidens is smaller than E. vizottoi, than in turn is similar in size to $E$. brunneum. In contrast, Pachycondyla striatula workers (Melo 2008) are larger than those of Ectatomma, but have shorter life expectancy. However, life expectancy seems to be determined by the sum of several factors.

In this study we observed that when workers begin to forage, life expectancy gradually decreases as described by Antonialli-Junior et al. (2007) for E. planidens workers. These authors attribute the decrease in life expectancy to greater exposure to certain factors such as greater energy or exposure to sunlight or ultraviolet rays. According to Gordon et al. (2005), foraging activity is low under laboratory conditions, and studies on life expectancy described a greater average longevity for the workers of E. planidens (Antonialli-Junior and Giannotti 2003, Antonialli-Junior et al. 2007) .The entropy value was $H=$ 0.920 , between $H=0.5$ and $H=1.0$, which indicates that many workers die in the first intervals of life. This high mortality rate during the first days of life might be associated with the stress caused by laboratory conditions, as suggested by Antonialli-Junior et al. (2007), or the paint used to mark newly emerged ants. According to Carey (1993), low entropy ( $H$ close to 0 ) indicates that individuals tend to die later, while entropy closer to 1 indicates a high mortality of young individuals. The entropy found for $E$. vizottoi explains the high mortality during the first 53 days. This same pattern of entropy was observed in E. planidens workers (Antonialli-Junior et al. 2007). In contrast, E. brunneum workers die on average near the 70th day (Tofolo and Giannotti 2005), which is a consequence of longer life expectancy. Although a pattern is likely to exist, individuals live longer under laboratory conditions than in the field, as a result of lower risk and energy expenditures (Hölldobler and Wilson 1990).

Our findings demonstrate that E. vizottoi workers exhibit a clear division of tasks throughout their lives, with young workers performing more tasks inside the colony and old workers, outside, although some tasks are performed by both groups. In spite of the number of deaths during the first intervals of life, which could induce foraging activity, workers of this species begin their activities outside the nest at an age similar to that of other species already studied. This species also exhibits an intermediary life expectancy compared to those of workers of other species that are also intermediary in size. This supports the hypothesis of a relationship between size and maximum life expectancy.

Acknowlegements The authors are thankful to Dr. Jacques Hubert Charles Delabie of the Laboratory of Myrmecology of the Center of Research of Cocoa (Centro de Pesquisa do Cacau-Ceplac-Ilhéus, BA), for the identification of the species. To Capes (Coordination for the Improvement of Higher Level Personnel) for the Master's Degree Fellowship granted to the first author, to FUNDECT (Foundation for the Support of Research of Mato Grosso do Sul), for financial support (Process No. 23/200.085/2007), and to CNPQ for thefellowship for scientific productivity granted to Dr. W. F. Antonialli-Junior.

Open Access This article is distributed under the terms of the Creative Commons Attribution Noncommercial License which permits any noncommercial use, distribution, and reproduction in any medium, provided the original author(s) and source are credited.

\section{References}

Agbogba C (1994) Absence age polyethism in the ponerinae ant Pachycondyla caffaria (Smith) (Hymenoptera: Formicidae): early especialization of the foragers. Behav process 32:47-52

Altmann J (1974) Observational study of behavior: sampling methods. Behaviour 49:227-267

Anderson C, McShea DW (2001) Individual versus social complexity, with particular reference to ant colonies. Biological reviews 76:211-237

Antonialli-Junior WF, Giannotti E (2001) Nest architecture and population dynamics of the ponerinae ant Ectatomma edentatum (Hymenoptera, Formicidae). Sociobiology 38:475-486

Antonialli-Junior WF, Giannotti E (2002) Division of labor in Ectatomma edentatum (Hymenoptera, Formicidae). Sociobiology 39:37-63

Antonialli-Junior WF, Giannotti E (2003) Age polyethism in workers of Ectatomma edentatum (Formicidae: Ponerinae). Sociobiology 41:461-478

Antonialli-Junior WF, Tofolo VC, Giannotti E (2007) Population dynamics of Ectatomma planidens (Hymenoptera: Formicidae) under laboratory conditions. Sociobiology 50:1005-1013 
Billen J (1982) Ovariole development in workers of Formica sanguine Latr. (Hymenoptera: Formicidae). Insect soc 29:86-94

Bolton B (2003) Synopsis and classification of formicidae. Florida, The American Entomological Institute, p 370

Bourke AFG, Franks NR (1995) Social evolution in ants. Princeton University Press, Princeton, p 526

Bourke AFG (1999) Colony size, social complexity and reproductive conflict in social insects. J evol biol 12:245-257

Breed MD, Harrison JM (1988) Worker size, ovary development and division of labor in the giant tropical ant, Paraponera clavata (Hymenoptera: Formicidae). J kans entomol soc 61:285-291

Caetano FH, Jaffé K, Zara FJ (2002) Formigas: biologia and anatomia. Rio Claro: Editora Topázio, pp. 131

Calabi P, Rosengaus R (1988) Interindividual differences based on behaviour transition probabilities in the ant Camponotus sericeiventris. In: Jeanne RL (ed) Interindividual behavioural variability in social insects. Westview, Boulder, Colo

Calabi P (1989) Behavioral flexibility in hymenoptera: are examination of the concept of caste. In: Trager EJ (ed) Advances in myrmecology. Brill Press, Leiden, pp 237-258

Cameron SA, Robinson GE (1990) Juvenile hormone does not affect division of labor in bumble bee colonies (Hymenoptera: Apidae). Entomol soc amer 83: 626-631

Cammaerts-Tricot MC, Verhaeghe JC (1974) Ontogenesis of trail pheromone production and trail following behaviour in the workers of Myrmica rubra L. (Hymenoptera: Formicidae). Insect Soc 21:275-282

Cammaerts-Tricot MC (1975) Ontogenesis of the defense reactions in the workers of Myrmica rubra L. (Hymenoptera: Formicidae). Anim behav 23:124-130

Higashi S (1974) Worker polyethism related with body size in a polydomous red wood ant, Formica (Formica) yessensis Forel. J Fac Sci Hokkaido Univ VI Zool 19:696-705

Carey JR (1993) Applied demography for biologists. New York, Oxford University Press, p 206

Champalbert A, Lachaud JP (1990) Existence of a sensitive period during the ontogenesis of social behaviour in a primitive ant. Anim Behav 39:850-859

Corbara B, Lachaud J-P, Fresneau D (1989) Individual variability, social structure and division of labour in the ponerine ant Ectatomma ruidum Roger (Hymenoptera, Formicidae). Ethology 82:89-100

Crosland MWJ, Lok CM, Wong TC, Shakarad M, Traniello JFA (1997) Division of labour in a lower termite: the majority of tasks are performed by older workers. Anim Behav 54:9991012

Dantas-de-Araújo CZ, Jaisson P (1994) Modes de fondation des colonies chez la fourmi sans reine Dinoponera quadriceps Santschi (Hymenoptera, Formicidae, Ponerinae). Actes colloq insectes soc 9:79-88

Dejean A, Lachaud JP (1991) Polyethism in the ponerinae ant Odontomachus troglodytes: Interaction of age and interindividual variability. Sociobiology 18:177-196

Fénéron R, Durand JL, Jaisson P (1996) Relation between behaviour and physiological maturation in ponerinae ant. Behaviour 133:791-806

Fénéron R, Jaisson P (1994) Ontogeny of social behavior and nestmate brood in a Ponerinae ant. In: 12th Congress of the International Union for the Study of Social Insects. p. 63

Fernandes FM, Lapola DM, Neregato R, de Carvalho MH, Von Zuben CJ (2003) Curva de sobrevivência and estimativa de entropia em Lucilia cuprina (Diptera, Calliphoridae). Iheringia Série Zoologia 93:319-324

Fresneau D (1984) Development ovarien et status social chez une fourmi primitive Neoponera obscuricornis Emery. Insect Soc $31: 387-402$
Fresneau D, Dupuy P (1988) A study of polyethism in a ponerine ant: Neoponera apicalis (Hymenoptera, Formicidae). Anim Behav 36:1389-1399

Fresneau D, Garcia-Pérez J, Jaisson P (1982) Evolution of polyethism in ants: observational results and theories. In: Jaisson P (ed) Social insects in the tropics. Press de I'Université Paris-Nord, Paris 1, pp 129-155

Gordon DM (1984) The persistence of role in exterior workers of the harvester ant, Pogonomyrmex badius. Psyche 91:251-266

Gordon DM, Chu J, Lillie A, Tissot M, Pinter N (2005) Variation in the transition from inside to outside work in the red harvester ant Pogonomyrmex barbatus. Insect soc 52:212-217

Gronenberg W (1996) Neuroethology of ants. Naturwissenschaften $83: 15-27$

Hölldobler B, Wilson EO (1990) The ants. The Belknap Press of Harvard University Press, Cambridge, p 732

Hora RR, Vilela E, Fénéron R, Pezon A, Fresneau D, Delabie J (2005) Facultative polygyny in Ectatomma tuberculatum (Formicidae, Ectatomminae). Insect soc 52:194-200

Ito F, Higashi S (1991) Alinear dominance hierarchy regulating reproduction and polyethism of queenless ant Pachycondyla sublaevis. Naturwissenschaften 78:80-82

Jaisson P, Fresneau DR, Leonir A (1992) Social organization in some primitive Australian ants. I. Nothomyrmecia macrops (Clack). Insect soc 39:425-438

Jeanne RL (1991) Polyethism. In: Ross KG and Matthews RW (eds). The Social Biology of Wasps. Cornell University Press, Ithaca. pp. $389-425$

Jeanne RL (1999) Group size, productivity, and information flow in social insects. In: Detrain C, Deneubourg JL, Pasteels JM (eds). Information processing in social insects. Birkhäuser Verlag, Basel. pp. 3-30

Krebs CJ (1994) Ecology: the experimental analysis of distribution and abundance. Harper \& Row, New York, p 801

Krüger RF, Erthal SG (2006) Estimativa de entropia de Muscina stabulans (Fallén) (Diptera, Muscidae) em condições artificiais. Rev Bras Entomol 50:275-279

McDonald P, Topoff H (1985) Social regulation of behavioral development in the ant, Novomessor albisetosus (Mayr). J comp psychol 99:3-14

MacDonald P, Topoff H (1988) Biological correlates of behavioral development in the ant, Novomessor albisetosus (Mayr). Behav neurosci 102:986-991

Masuko K (1996) Age division of labor among workers in the Ponerinae ant, Amblyopone silvestrii (Hymenoptera: Formicidade). Sociobiology 28:131-151

Melo AS (2008) Modelo arquitetônico de ninhos, biologia e divisão de trabalho de Pachycondyla striata Fr. Smith, 1858 (Hymenoptera: Formicidae: Ponerinae). Dissertação de mestrado-UNESP. p. 114

Miguel TB, Del-Claro K (2005) Polietismo etário and repertório comportamental de Ectatomma opaciventre Roger, 1861 (Formicidae, Ponerinae). Revista Brasileira de Zoociências 7:297-310

Möglich M, Hölldobler B (1974) Social carrying behavior and division of labor during nest moving in ants. Psyche: A Journal of Entomology 81:219-236

Nakata K (1996) The difference in behavioral flexibility among task behaviors in a Ponerinae ant, Diacamma sp. Sociobiology 27:119-128

O'Donnell S, Jeanne RL (1993) Methoprene accelerates age polyethism in workers of a social wasp (Polybia occidentalis). Physical Entomology 18:189-194

Oster G, Wilson EO (1978) Caste and ecology in the social insects, vol 12. Princeton University Press, Princeton, pp 1-352

Overal WL (1986) Recrutamento e divisão de trabalho em colônias naturais da formiga Ectatomma quadridens (Fabr.) (Hymenoptera: Formicidae: Ponerinae). Bol Mus Para Emiâlio Goeldi, Zool 2:113-135 
Pérez-Bautista M, Lachaud J-P, Fresneau D (1985) La division de trabajo en la hormiga primitiva Neoponera villosa (Hymenoptera: Formicidae). Folia Entomol Mex 65:119-130

Pie MR (2002) Behavioral repertoire, age polyethism and adult transport in Ectatomma opaciventre (Formicidae: Ponerinae). J insect behav 15(1):25-35

Post DC, Jeanne RL, Erickson EHJr (1988) Variation in behavior among workers of the primitively social wasp Polistes fuscatus variatus. In: Jeanne, RL (eds). Interindividual behavioral variability in social insects. Westview Press, Boulder, Colo. pp. 283322.

Pratt SC (1994) Ecology and behavior of Gnamptogenys horni (Formicidae: Ponerinae). Insect soc 41:255-262

Pratt SC, Carlin NF, Calabi P (1994) Division of labor in Ponera pennsylvannica (Formicidae: Ponerinae). Insect soc 41:43-61

Retana J, Cerdá X (1991) Behavioural variability and development of Cataglyphis cursor ant workers (Hymenoptera, Formicidae). Ethology 89:275-286

Robinson GE, Page RE Jr, Huang ZY (1994) Temporal polyethism in social insects is a developmental process. Anim behav 48:467469

Rosengren R (1977) Foraging strategy of wood ants (Formica rufa group) I. Age polyethism and topographic traditions. Acta Zoological Fennica 149:1-30

Silveira Neto S, Nakano O, Barbin D, Nova NAV (1976) Manual de ecologia dos insetos. Agronômica Ceres, São Paulo. p. 419

Tofolo VC, Giannotti E (2005) Population Dynamics of Ectatomma brunneum (Hymenoptera, Formicidae) Under laboratory conditions. Sociobiology 46:627-636
Thomas ML (2002) Causes and consequences of colony size in the ponerine ant Rhytidoponera metallica. Ph.D. thesis, University of Melbourne, Australia.

Thomas ML, Elgar MA (2003) Colony size affects division of labour in the ponerine ant Rhytidoponera metallica. Naturwissenschaften 90:88-92

Traniello JF (1978) Caste in a primitive ant: absence of age polyethism in Amblyopone. Science 202:770-772

Vieira AS, Antonialli-Junior WF, Fernandes WD (2007) Modelo arquitetônico de ninhos da formiga Ectatomma vizottoi Almeida (Hymenoptera, Formicidae). Rev bras entomol $51: 313-317$

Villet MH (1990) Social organization of Platythyrea lamellosa (Roger) (Hymenoptera: Formicidae): II. Division of labor. S afr j zool 25:254-259

Weir JS (1958) Polyethism in workers of the ant Myrmica I. Insect soc 5:97-128

Wheeler WM (1910) Ants: their structure, development and behavior. Columbia University Press, New York

Wilson EO (1971) The insect societies. Harvard University Press, Cambridge

Wilson EO, Hölldobler B (1986) Ecology and behavior of the neotropical cryptobiotic and Basiceros manni (Hymenoptera: Formicidae: Basicerotini). Insect soc 33:70-84

Wilson EO, Brown WL Jr (1984) Behavior of the cryptobiotic predaceous ant Eurhopalothrix heliscata, n. sp. (Hymenoptera: Formicidae: Basicerotini). Insect soc 31:408-428

Wolda H (1981) Similarity indices, sample size and diversity. Oecologia 50:296-302 